\title{
SFPQ wt Allele
}

National Cancer Institute

\section{Source}

National Cancer Institute. SFPQ wt Allele. NCI Thesaurus. Code C71418.

Human SFPQ wild-type allele is located in the vicinity of 1 p34.3 and is approximately $17 \mathrm{~kb}$ in length. This allele, which encodes splicing factor, proline- and glutamine-rich protein, may play a role in the modulation of RNA processing, transcription and DNA secondary structure. The gene can be involved in a translocation $t(X ; 1)(p 11.2 ; p 34)$ with the TFE3 gene in some papillary renal cell carcinomas. 